\title{
DEVELOPING A NEW APPROACH FOR EVALUATION OF BUSINESS PROCESSES IN A FUZZY ENVIRONMENT
}

\author{
Ghasem BAGHERZADEH ${ }^{\mathrm{a}}$, Kaveh M. CYRUS ${ }^{\mathrm{b}}$, \\ Abdolreza YAZDANI-CHAMZINIc ${ }^{c}$, Algita MIEČINSKIENE ${ }^{\mathrm{d}}$ \\ ${ }^{a, b}$ Department of Industrial Engineering \& Management Systems, \\ Amirkabir University of Technology (Tehran Polytechnic), Tehran, Iran \\ ${ }^{c}$ Young Researchers and Elite Club, South Tehran Branch, \\ Islamic Azad University, Tehran, Iran \\ ${ }^{d}$ Department of Finance Engineering, Faculty of Business Management, \\ Vilnius Gediminas Technical university, Sauletekio al. 11, LT-10223 Vilnius, Lithuania
}

Received 11 May 2016; accepted 4 August 2016

\begin{abstract}
Evaluation of business processes plays a significant role in business development and improvement. Therefore, organizations need a systematic approach to evaluate all the changes through robust and powerful techniques that can formulate the relationship between the available information and the degree of the inherent uncertainty. In this paper, a set of operational variables are defined. Then, the SPSS software package is utilized to validate the gathered data. After that, the variables are categorized by the use of a clustering technique. Finally, five major factors are determined as the most effective components. According to the inherent uncertainty involved in the process of modelling, fuzzy set theory, a powerful mathematical tool is applied to handle the vagueness. In order to construct a knowledge base based on the fuzzy set theory, the linguistic concepts for each variable are defined. Lastly, membership functions are described and a set of fuzzy rules based on input-output parameters are written in MATLAB software environment. To demonstrate the potential application of the proposed approach, a real case study is illustrated. The results reflect the capability and effectiveness of the approach proposed in this paper.
\end{abstract}

Keywords: fuzzy inference system, assessment of BPM and BPR, bank payment systems, exploratory factor analysis, process improvement.

JEL Classification: D81, E42, M21, C02.

Corresponding author Algita Miečinskienè

E-mail: algita.miecinskiene@vgtu.lt 


\section{Introduction}

Many productions were made by the skilled craftsmen until the mid-seventeenth century, and all phases of design, manufacture, marketing, sales and service in various industries such as textile, metals, jewellery, etc., was implemented in craftsmen's small workshop. After the invention of the steam engine by James Watt (1775), Adam Smith in his book - An Inquiry into the Nature and Causes of the Wealth of Nations - announced the appearance of industrial revolution (Smith 1776).

In the late of twentieth century, revolution and transformation appeared in organizations and companies. This era was famous for a sudden appearance and a sudden disappearance of wealth because of the continuous revolution. Gary Hamel encouraged managers to destroy - smash - the old models and business strategies and to create new ones (Binesh 2005; Hamel 2009). He believed that for doing so we should not regard a thing which is transforming as a stable thing. He mentioned that we should give up using the old patterns and change our perception. In order to do that, we should quit using current business models which stick to imagination and loyalty and create totally different models to compete with our traditional rivals. In order to reach the highest level of ability and be successful in competitions, organizations need to accept changes and use the cutting-edge technology. They should also reach the stable and continuous level in the business. One of the well-known ways to bring these ideas into practice is process reengineering.

One of the main differences of organization reengineering in comparison to other managerial approaches is the deep transformation that it brings in the way of doing activities in organizations. The implementation and deployment of the approach is more complex than other management approaches. Because of the complexity, approximately $70 \%$ of reengineering projects are failed in practice (Champy 1995). Due to this fact, reengineering can considered to be a high risk activity for organizations.

Successful organizations are inevitably forced to change their structure from function-oriented to process-oriented (Obolensky 1997). However, due to the uncertainty in creating additional value in future changes, implementation of temporary or permanent changes is always offending. For this reason, a systematic mechanism is needed to evaluate the designed business process (Podviezko, Podvezko 2014; Susniene, Purvinis 2015; Treki, Urban 2015; Morselli 2015; Meyer, Zimmermann 2011). It is obvious that every qualified person has his/her own design, but in the process restructuring, all the effects and consequences should be considered and experts should comment on it. In fact, these effects and consequences are the influential factors, including all the related aspects, in the success of business processes. Moreover, expert opinions and quantitative data play a key role in formulating a problem. The merit of using the fuzzy logic is to handle the uncertainty arisen from less/lack of information in the process of modelling (Efendigil 2009; Baležentis et al. 2012; Nouri et al. 2015; Stanujkic et al. 2015; Yazdani-Chamzini et al. 2014; Rikhtegar et al. 2014; Khandekar et al. 2015). This tool helps decision makers to express the input-output relationships in the form of a linguistic value instead of a crisp one.

In the beginning of the study, process-related indicators were identified by literature review process (Bausys et al. 2015; Bausys, Zavadskas 2015; Akhavan et al. 2015; Kaya, 
Kahraman 2014; Ferreira et al. 2014; Binesh 2005) and interview with the academic and professional experts with a high background in the field of banking payment system. As well as, other indicators and process-related parameters by the use of questionnaires and experts' information were identified. Then, the indicators by the use of statistical analysis were validated and the related weights were calculated. Next, a set of fuzzy input-output rules were established in MATLAB software environment. Lastly, in the final phase of the process, the priority of the suggested processes of banking payment system was determined by decision maker team. For better understanding, the process is shown in Figure 1. It should be noted that the process is modifiable and reviewable.

In this study, the Cronbach's alpha in SPSS software was applied to measure the stability of the questionnaires. As well as, factor analysis was used to identify the evaluation indicators in order to find the main and influential factors of the final process.

Likewise, the fuzzy inference system, the heart of the system, is employed for scoring the processes by the use of MATLAB software. In this system, the values and their corresponding weights of each indicator are considered as input parameters for scoring the process.

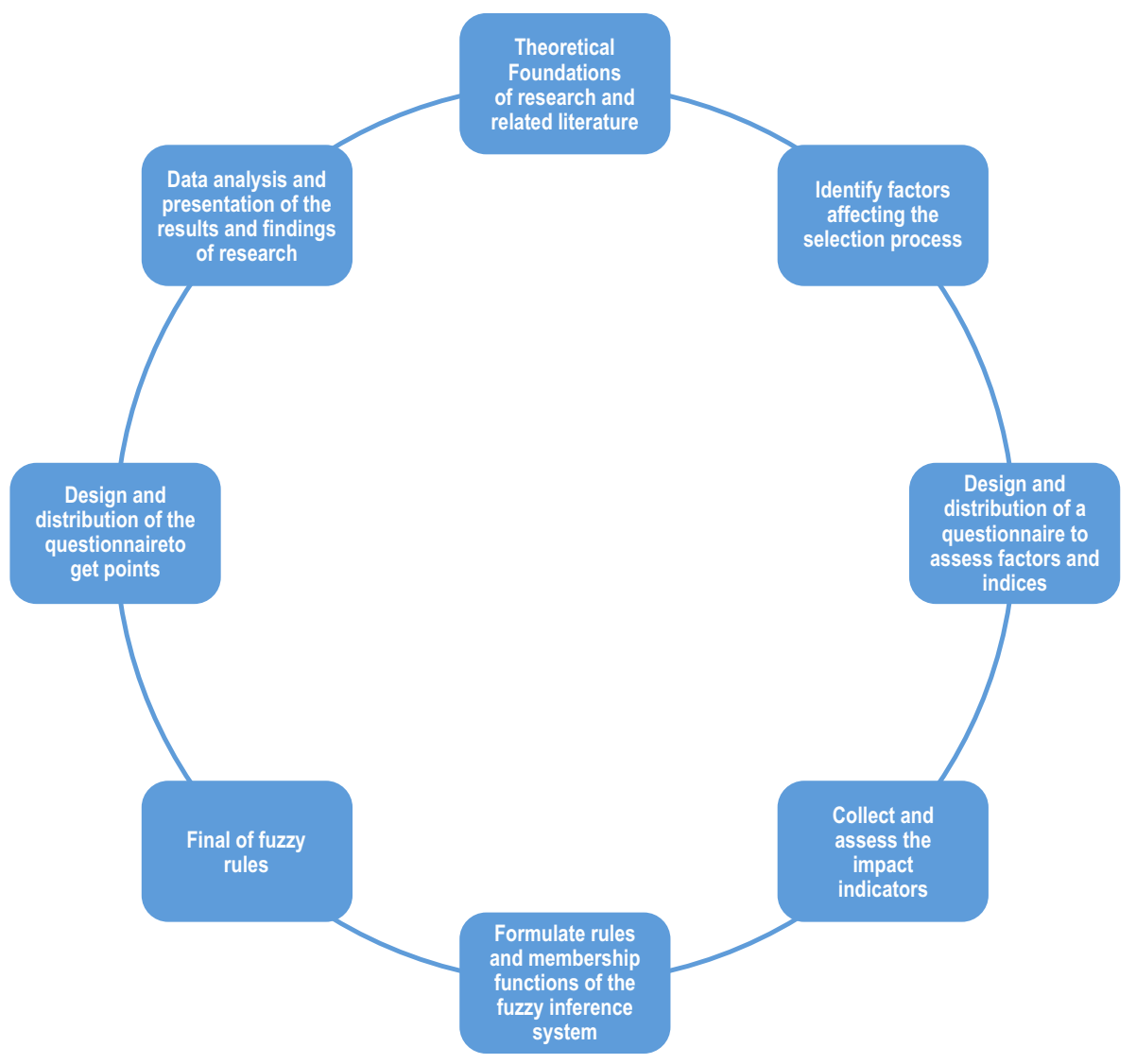

Fig. 1. The proposed methodology 


\section{Examining the classified indicators to measure systems}

Nowadays, performance measurement has caught the eyes of managers. As Neely mentions, the number of conferences held for measuring business performance by organizations such as the Institute for International Research (IIS) and Business Intelligence are increasing (Neely 1999). Also the Britain's Royal Society of Arts, Manufacturers and Commerce (RSA) announced in its 1994 agreement that companies should measure their processes performance to achieve business success in the global marketplace.

By reviewing literatures, we can conclude that during these years numerous authors (e.g. Efendigil 2009, Obolensky 1997), have attempted to introduce various aspects of systems and proposed their indicators in accordance to them. Some authors tried to design a system for a specific goal by specifying some indicators and dimensions.

Imagine that there is lack of resources in a personal life; of course, it is a difficult life which people are encountered with a lot of challenges in it. There is more complexity and difficulty in organizations because of the emergence of more and more indicators and acute problems. Flexibility, time, cost and quality are the examples of the effective indicators in organization (Delgado et al. 2014). Also there are more effective indicators such as internal factors (performance) and external factors (effectiveness), lean manufacturing, competition, cost management, jobs creation and added value, growth and raises Viable Corporation.

Various indicators classifications are also done by different researchers (Neely, Gregory 1995; Kaplan, Norton 1992; Brignall et al. 1991; Globerson, Ellis 1996; Maskell 1989; Davis, Blenkinsop 1991; Wisner, Fawcett 1991; Fry, Cox 1989; Neely, Adams 2002; Neely 1998).

The specifications, business processes and the results should be monitored and scored in accordance to the demands of the stakeholders. Therefore, due to the given complexity of the process performance, the organization and its interactions with the environment can be understood. From another viewpoint or prospective, the leading indicators will provide a condition for breeding performance, while the lagging indicators just express the historical events. Therefore, it is essential to use an effective performance measurement system in organizations. The effectiveness of the business process in performance management depends on how to use the collected information (Teymori, Aliakbari 2009). Table 1 shows the total of 30 identified indicators and their references.

According to the key importance of the problem, during the late nineteenth century, a number of researches have been conducted to develop new indicators in order to measure the performance of business process, including Financial Ratio (Foster 1986), Triangular system of proportion of DuPont (Karami, Talaeei 2013), Activity-Based Costing (Neely, Gregory 1995), Performance measurement Matrix (Keegan et al. 1989), Benchmarking (Wainwright et al. 2005), Strategic measurement analysis and reporting technique (Lynch, Cross 1991), Bringnall and Ballantine method (Brignall, Ballantine 1996), Balanced Scorecard (Kaplan, Norton 1992), Integrated Dynamic Performance measurement System (Ghalayini et al. 1997), Tableau de bord (Epstein, Manzoni 1997), Performance Prism (Neely et al. 2000), absolute and relative evaluation (Podviezko, Podvezko 2014), Analytical Hierarchy Process (Saaty 1980), the analytic network process (Boran et al. 2008), Fuzzy Analytic Hierarchy Process (Buckley 1985). 
Table 1. The effective indicators of business processes

\begin{tabular}{|c|c|c|c|}
\hline No & References & $\begin{array}{l}\text { Process } \\
\text { indicators }\end{array}$ & $\begin{array}{l}\text { Corresponding } \\
\text { questions in the } \\
\text { questionnaire }\end{array}$ \\
\hline 1 & $\begin{array}{l}\text { Delgado et al. 2014; Kennerley, Neely 2002; Mansar, } \\
\text { Reijers 2007; Trkman 2010; Zarandi } 2011\end{array}$ & Integration & $1-2$ \\
\hline 2 & $\begin{array}{l}\text { Kennerley, Neely 2002; Delgado et al. 2014; Teymori, } \\
\text { Aliakbari 2009; Reijers, Mansar 2005; Trkman 2010, } \\
\text { Mansar, Reijers 2007; Reijers, Mansar 2005; Temponi, } \\
\text { Harris } 1998\end{array}$ & Flexibility & 3 \\
\hline 3 & Delgado et al. 2014; Motamedifar 2008 & Security & $4-13$ \\
\hline 4 & Delgado et al. 2014; Zarandi 2011; Wu 2009 & Agility & 14 \\
\hline 5 & Delgado et al. 2014; Trkman 2010 & Collectivity & $15-16$ \\
\hline 6 & Trkman 2010, Wu 2009, Treki, Urban 2015 & Risk management & $17-20$ \\
\hline 7 & Delgado et al. 2014; Mansar, Reijers 2007 & Centralization & $21-22$ \\
\hline 8 & Mansar, Reijers 2007; Trkman 2010 & $\begin{array}{l}\text { Bureaucratic } \\
\text { formality }\end{array}$ & 23 \\
\hline 9 & Delgado et al. 2014; Mansar, Reijers 2007; Trkman 2010 & Team working & 24 \\
\hline 10 & Neely et al. 2000; Teymori, Aliakbari, 2009; Trkman 2010 & Innovation & 25 \\
\hline 11 & Neely et al. 2000; Delgado et al. 2014 & $\begin{array}{l}\text { Internal customer } \\
\text { satisfaction }\end{array}$ & $26-29$ \\
\hline 12 & $\begin{array}{l}\text { Delgado et al. 2014, Teymori, Aliakbari 2009; Reijers, } \\
\text { Mansar 2005; Temponi, Harris 1998; Zarandi } 2011\end{array}$ & Saving time & 30 \\
\hline 13 & Zarandi 2011; Afrazeh 2011 & $\begin{array}{l}\text { Capital } \\
\text { knowledge }\end{array}$ & $31-33$ \\
\hline 14 & $\begin{array}{l}\text { Delgado et al. 2014; Zarandi 2011; Teymori, Aliakbari } \\
\text { 2009; Bourne 2000; Temponi, Harris 1998; Trkman } 2010\end{array}$ & Profitability & $34-35$ \\
\hline 15 & $\begin{array}{l}\text { Delgado et al. 2014; Reijers, Mansar 2005; Mansar, Reijers } \\
\text { 2007; Trkman 2010; Zarandi 2011; Temponi, Harris } 1998\end{array}$ & Saving money & $36-37$ \\
\hline 16 & Wu 2009 & $\begin{array}{l}\text { Senior } \\
\text { management } \\
\text { satisfaction }\end{array}$ & $38-39$ \\
\hline 17 & Zarandi 2011; Mansar, Reijers 2007 & $\begin{array}{l}\text { Senior } \\
\text { management } \\
\text { support }\end{array}$ & $40-41$ \\
\hline 18 & Delgado et al. 2014 & User friendly & $42-43$ \\
\hline 19 & $\begin{array}{l}\text { Delgado et al. 2014; Spremic, Zmirak 2008; Mansar, } \\
\text { Reijers 2007; Maull } 2003\end{array}$ & Maturity & $44-45$ \\
\hline 20 & Delgado et al. 2014; Mansar, Reijers 2007 & Self control & $46-47$ \\
\hline 21 & Delgado et al. 2014; Mansar, Reijers 2007 & Contribution & $48-50$ \\
\hline 22 & Delgado et al. 2014; Trkman 2010 & Competition & 51 \\
\hline 23 & $\begin{array}{l}\text { Kennerley, Neely 2002; Delgado et al. 2014; Mombeini } \\
\text { et al. } 2014\end{array}$ & $\begin{array}{l}\text { Software and } \\
\text { hardware } \\
\text { performance }\end{array}$ & $52-54$ \\
\hline 24 & $\begin{array}{l}\text { Delgado et al. 2014; Teymori, Aliakbari 2009; Susniene, } \\
\text { Purvinis } 2015\end{array}$ & Reliability & $55-56$ \\
\hline
\end{tabular}


End of Table 1

\begin{tabular}{lllc}
\hline No & \multicolumn{1}{c}{ References } & \multicolumn{1}{c}{$\begin{array}{c}\text { Process } \\
\text { indicators }\end{array}$} & $\begin{array}{c}\text { Corresponding } \\
\text { questions in the } \\
\text { questionnaire }\end{array}$ \\
\hline 25 & Spremic, Zmirak 2008 & Transparency & $57-58$ \\
\hline 26 & Zarandi 2011; Temponi, Harris 1998 & $\begin{array}{l}\text { Training courses } \\
\text { and continuous }\end{array}$ & $59-60$ \\
\hline 27 & $\begin{array}{l}\text { Zarandi 2011; Delgado } \text { et al. 2014; Teymori, Aliakbari } \\
\text { 2009; Reijers, Mansar 2005; Temponi, Harris 1998 }\end{array}$ & $\begin{array}{l}\text { Acceleration } \\
\text { process }\end{array}$ & 61 \\
\hline 28 & Delgado et al. 2014; Trkman 2010 & Adaptation & 62 \\
\hline 29 & $\begin{array}{l}\text { Delgado } \text { et al. 2014, Trkman 2010; Bourne 2000; Reijers, } \\
\text { Mansar 2005; Azizi } \text { et al. 2014 }\end{array}$ & $\begin{array}{l}\text { Customer } \\
\text { satisfaction }\end{array}$ & $63-65$ \\
\hline 30 & Delgado et al. 2014; Trkman 2010 & $\begin{array}{l}\text { Feedback and } \\
\text { monitoring }\end{array}$ & $66-67$ \\
\hline
\end{tabular}

\section{An approach for evaluating BPM and BPR by fuzzy inference system}

\subsection{Exploratory factor analysis results}

Descriptive and inferential statistics. In the present study, the techniques of descriptive statistics including frequency tables, the analyzed data related to demographics, Cronbach's alpha formula and factor analysis are used to investigate the problem under consideration. Some descriptive statics are presented as follows:

- The most frequent ages are between 36-45 years old.

- Levels of education contain of $37.3 \%$ college graduate, $61.4 \%$ postgraduate, and $1.2 \% \mathrm{PhD}$.

- Statistical society comprises of $69.9 \%$ expert, $12 \%$ deputy director, $4.8 \%$ head of department, $4.8 \%$ senior management, and $8.4 \%$ other positions.

- The highest frequency is related to working experience between 11 and 20 years.

- The rate of gender of respondents is $79.5 \%$ male and $20.5 \%$ female.

Reliability. The designed questionnaire was distributed among 95 experts in the field of processes reengineering and 83 questionnaires were returned (the return rate is $83 \%$ ). The reliability of the questionnaire was evaluated and the results are presented in Table 2 . The total Cronbach's alpha number for this questionnaire was equal to 0.963 , which is a suitable amount for this study.

Validity. Exploratory factor analysis method was employed to ensure the validity of the questionnaires. Generally, it can be said that the exploratory factor analysis pursues three goals (Anderson, Gerbing 1988):

- Data reduction,

- Structure detection,

- Divergent validity.

The results based on the factor analysis show that the Kaiser-Meyer-Olkin (KMO) index is greater than 0.5 . This shows that the number of samples is sufficient for factor analysis (Field 2000). 
Table 2. Cronbach's alpha indicators

\begin{tabular}{ccc}
\hline Cronbach's Alpha & Variable & No of items \\
\hline 0.724 & Integration & 2 \\
\hline 0.884 & Security & 10 \\
\hline 0.508 & Collectivity & 2 \\
\hline 0.821 & Risk management & 4 \\
\hline 0.875 & Centralization & 2 \\
\hline 0.851 & Internal customer satisfaction & 4 \\
\hline 0.895 & Capital knowledge & 3 \\
\hline 0.84 & Profitability & 2 \\
\hline 0.504 & Saving money & 2 \\
\hline 0.685 & Senior management satisfaction & 2 \\
\hline 0.794 & Senior management support & 2 \\
\hline 0.834 & User friendly & 2 \\
\hline 0.749 & Maturity & 2 \\
\hline 0.793 & Self control & 2 \\
\hline 0.809 & Contribution & 2 \\
\hline 0.865 & Feedback and monitoring & 2 \\
\hline 0.682 & All & 2 \\
\hline 0.827 & Transparency & 2 \\
\hline 0.793 & Software and hardware performance & 2 \\
\hline 0.81 & Reliability & 3 \\
\hline 0.934 & Tustomer satisfaction & 2 \\
\hline 0.963 & & 2 \\
\hline & Traing courses and continuous & 2 \\
\hline & & 2 \\
\hline & & 2 \\
\hline
\end{tabular}

The parameters are grouped according to the results of the confirmatory factor analysis. The average indicator for the 67 questions was related to 30 main indicators. The KMO values are calculated for 30 indicators that are shown in Table 3.

Table 3. KMO and Bartlett's Test

\begin{tabular}{ccc}
\hline \multicolumn{2}{c}{ Kaiser-Meyer-Olkin Measure of Sampling Adequacy. } & 0.791 \\
\hline & Approx. Chi-Square & 1277.329 \\
Bartlett's Test of Sphericity & df & 435 \\
& Sig. & 0.000 \\
\hline
\end{tabular}

The value of 0.791 for the KMO indicator is a confirmation for adequacy of accomplishing a factor analysis method. Then, the numbers of factors are determined. As seen in Table 4, only 5 factors have the special values more than one. These 5 factors together explain $70 \%$ of variability and show that they are qualified to be selected.

Each parameter is allocated to these 5 factors by the use of the factor matrix or rotated factor matrix in Table 5. 
Table 4. 30 indicators of factor analysis

\begin{tabular}{|c|c|c|c|c|c|c|c|c|c|}
\hline & \multicolumn{3}{|c|}{ Initial Eigenvalues } & \multicolumn{3}{|c|}{$\begin{array}{l}\text { Extraction Sums of Squared } \\
\text { Loadings }\end{array}$} & \multicolumn{3}{|c|}{$\begin{array}{c}\text { Rotation Sums of Squared } \\
\text { Loadings }\end{array}$} \\
\hline & 퓽 & 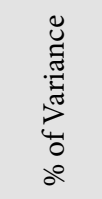 & 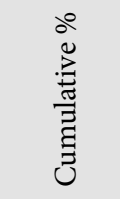 & $\stackrel{\text { تేँ }}{0}$ & 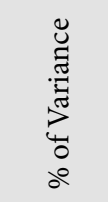 & 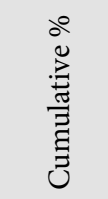 & 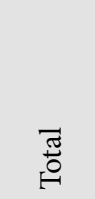 & 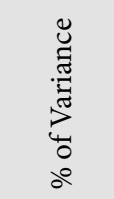 & 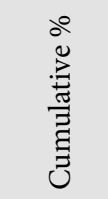 \\
\hline 1 & 12.615 & 42.051 & 42.051 & 12.615 & 42.051 & 42.051 & 5.134 & 17.114 & 17.114 \\
\hline 2 & 2.398 & 7.995 & 50.046 & 2.398 & 7.995 & 50.046 & 4.792 & 15.972 & 33.086 \\
\hline 3 & 2.161 & 7.203 & 57.249 & 2.161 & 7.203 & 57.249 & 4.411 & 14.704 & 47.790 \\
\hline 4 & 1.540 & 5.132 & 62.381 & 1.540 & 5.132 & 62.381 & 4.196 & 13.987 & 61.777 \\
\hline 5 & 1.363 & 4.544 & 66.924 & 1.363 & 4.544 & 66.924 & 1.544 & 5.148 & 66.924 \\
\hline 6 & 0.998 & 3.816 & 70.741 & & & & & & \\
\hline 7 & 0.980 & 3.266 & 74.007 & & & & & & \\
\hline 8 & 0.896 & 2.988 & 76.995 & & & & & & \\
\hline 9 & 0.791 & 2.636 & 79.630 & & & & & & \\
\hline 10 & 0.708 & 2.360 & 81.990 & & & & & & \\
\hline 11 & 0.653 & 2.177 & 84.167 & & & & & & \\
\hline 12 & 0.633 & 2.109 & 86.276 & & & & & & \\
\hline 13 & 0.495 & 1.649 & 87.925 & & & & & & \\
\hline 14 & 0.469 & 1.564 & 89.489 & & & & & & \\
\hline 15 & 0.408 & 1.360 & 90.849 & & & & & & \\
\hline 16 & 0.394 & 1.314 & 92.163 & & & & & & \\
\hline 17 & 0.365 & 1.218 & 93.381 & & & & & & \\
\hline 18 & 0.284 & 0.948 & 94.329 & & & & & & \\
\hline 19 & 0.269 & 0.898 & 95.226 & & & & & & \\
\hline 20 & 0.255 & 0.848 & 96.075 & & & & & & \\
\hline 21 & 0.225 & 0.750 & 96.825 & & & & & & \\
\hline 22 & 0.186 & 0.621 & 97.446 & & & & & & \\
\hline 23 & 0.175 & 0.585 & 98.030 & & & & & & \\
\hline 24 & 0.135 & 0.451 & 98.481 & & & & & & \\
\hline 25 & 0.126 & 0.420 & 98.901 & & & & & & \\
\hline 26 & 0.105 & 0.351 & 99.252 & & & & & & \\
\hline 27 & 0.079 & 0.263 & 99.515 & & & & & & \\
\hline 28 & 0.059 & 0.196 & 99.712 & & & & & & \\
\hline 29 & 0.047 & 0.158 & 99.870 & & & & & & \\
\hline 30 & 0.039 & 0.130 & 100.000 & & & & & & \\
\hline
\end{tabular}


Table 5. Factor rotation for 30 indicators

\begin{tabular}{|c|c|c|c|c|c|}
\hline & \multicolumn{5}{|c|}{ Component } \\
\hline & 1 & 2 & 3 & 4 & 5 \\
\hline var1 & -0.123 & 0.450 & 0.550 & 0.375 & -0.064 \\
\hline var2 & 0.302 & 0.259 & 0.658 & -0.041 & -0.060 \\
\hline var3 & -0.016 & 0.786 & 0.152 & 0.090 & -0.059 \\
\hline var4 & 0.100 & 0.083 & 0.786 & 0.323 & 0.128 \\
\hline var5 & 0.296 & 0.281 & 0.649 & 0.202 & -0.224 \\
\hline var6 & 0.147 & 0.606 & 0.491 & 0.231 & -0.075 \\
\hline var7 & 0.015 & 0.215 & 0.229 & 0.279 & -0.681 \\
\hline var8 & 0.072 & 0.174 & 0.749 & 0.213 & -0.048 \\
\hline var9 & -0.006 & -0.012 & 0.066 & 0.762 & -0.313 \\
\hline var10 & 0.115 & 0.049 & 0.451 & 0.680 & 0.012 \\
\hline var11 & 0.335 & 0.232 & 0.206 & 0.625 & 0.164 \\
\hline var12 & 0.220 & 0.689 & 0.095 & 0.277 & -0.197 \\
\hline var13 & 0.284 & 0.223 & 0.217 & 0.797 & -0.113 \\
\hline var14 & 0.053 & 0.509 & 0.149 & 0.413 & 0.604 \\
\hline var15 & 0.293 & 0.645 & 0.226 & 0.176 & 0.053 \\
\hline var16 & 0.413 & 0.233 & 0.210 & 0.580 & 0.173 \\
\hline var17 & 0.511 & 0.249 & 0.616 & 0.187 & 0.044 \\
\hline var18 & 0.299 & 0.707 & 0.186 & 0.073 & 0.076 \\
\hline var19 & 0.424 & 0.241 & 0.071 & 0.568 & 0.127 \\
\hline var20 & 0.340 & 0.482 & 0.452 & -0.033 & 0.159 \\
\hline var21 & 0.596 & 0.161 & 0.233 & 0.440 & 0.017 \\
\hline var22 & 0.407 & -0.063 & 0.355 & 0.388 & 0.404 \\
\hline var23 & 0.666 & 0.291 & 0.336 & 0.133 & 0.064 \\
\hline var24 & 0.458 & 0.643 & 0.160 & 0.016 & 0.014 \\
\hline var25 & 0.614 & 0.467 & 0.215 & 0.159 & -0.178 \\
\hline var26 & 0.610 & 0.116 & 0.044 & 0.427 & 0.045 \\
\hline var27 & 0.873 & 0.069 & -0.014 & 0.157 & -0.098 \\
\hline var28 & 0.524 & 0.345 & 0.328 & 0.199 & 0.200 \\
\hline var29 & 0.578 & 0.512 & 0.135 & -0.011 & 0.339 \\
\hline var30 & 0.670 & 0.256 & 0.470 & 0.202 & 0.060 \\
\hline
\end{tabular}


Based on the exploratory factor analysis and the rotation factor loadings, 30 indicators were classified into 5 groups, as described in Table 6 .

Finally, after accomplishing the exploratory factor analysis, based on the experts' opinion, the following factors have been selected as the representation of those 30 indicators and the obtained average weights are shown in Table 7:

- Time,

- Reliability,

- Flexibility,

- Human Factor,

- Profitability.

Table 6. The table of the business process with average indicators

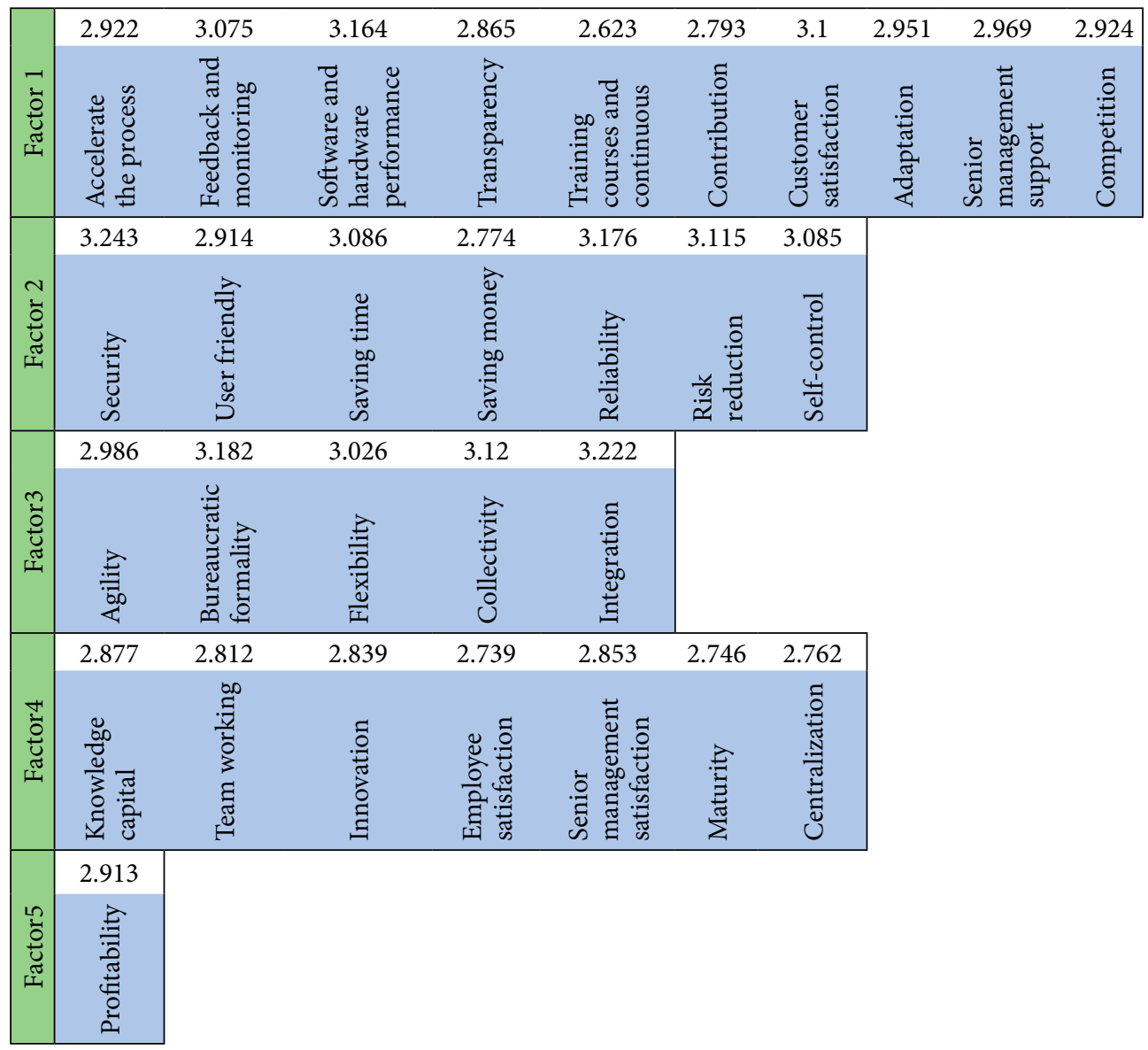

Table 7. Final average weight

\begin{tabular}{lccccc}
\hline Factor & Time (T) & Reliability (R) & Flexibility (F) & Human (H) & Profitability (P) \\
\hline $\begin{array}{l}\text { Mean } \\
\text { Number }\end{array}$ & 2.9381 & 3.0523 & 3.1146 & 2.8063 & 2.9135 \\
\hline
\end{tabular}




\subsection{Fuzzy Inference System is designed for system measurement}

Generally, the fuzzification takes place in the first phase of fuzzy systems by membership functions; so that, the input indicators are converted to linguistic variables. Then, using fuzzy rules, the fuzzy input is converted to the fuzzy output, which is done by the inference engine. Then in the final stage, the output of the fuzzy inference engine is defuzzified by using a defuzzification process. These steps are depicted in Figure 2.

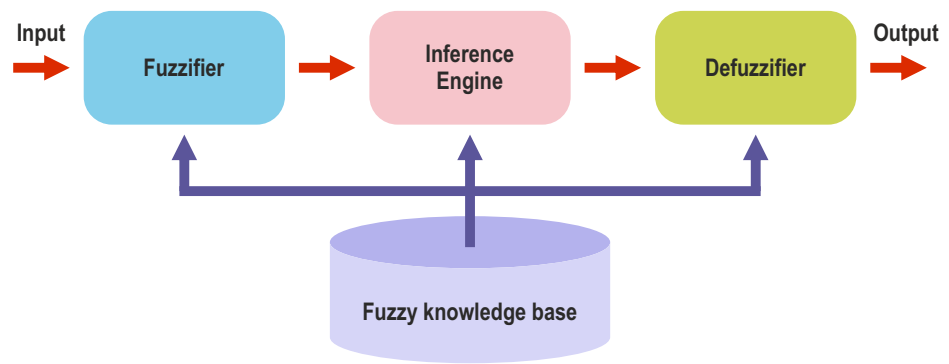

Fig. 2. Overview of the fuzzy systems

Fuzzy sets and membership functions are defined to design a fuzzy inference system. Since the main five factors time, reliability, flexibility, human and profitability, which are the most effective factors on business process, were identified as the five factors of fuzzy set for the implementation of the process of the business evaluation. In order to construct the fuzzy model, the input and output parameters using membership functions are defined and then the fuzzy rules are written. At last, the output values were produced by using centroid defuzzification method.

The overview of the fuzzy inference system is shown in Figure 3. The left side graph shows the membership function of the fuzzy sets that is used as the input of the fuzzy inference system. The middle graph represents the inference rules that derive the system and convert the inputs into outputs. The right side graph represents the evaluation process of the organization. In this paper, MATLAB software package (2011 version) is used to analyze and design the fuzzy inference system.

In the following section, the membership functions of the fuzzy sets are described. There are three ways to select the membership functions (Zarandi 2010):

- Ask an expert about fitting of the sample with membership function.

- Using curve-fitting method for determining the best compliance with the selected sample and selecting the membership functions such as triangular functions, trapezoidal, bell or etc.

- Using techniques of fuzzy and neural-fuzzy network for creating and optimizing the parametric membership functions.

In this paper, the experts' opinion is applied to select the type of membership function. According to the experts' opinion, the triangular membership function is adopted. For achieving the aim, three linguistic terms including low $(\mathrm{L})$, medium $(\mathrm{M})$ and high $(\mathrm{H})$ for each of the membership functions are defined. Table 8 represents how to use these linguistic variables. 


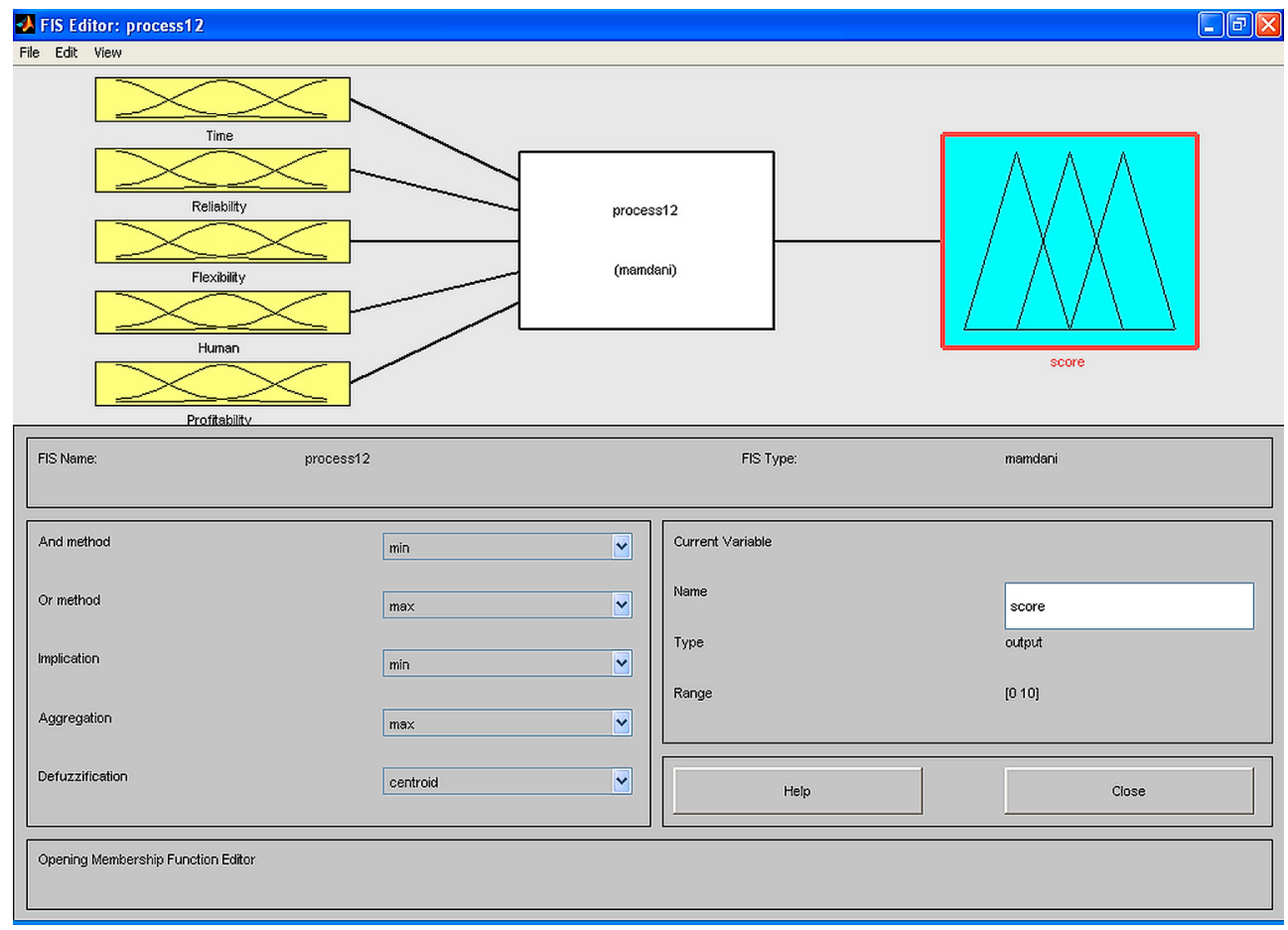

Fig. 3. Input and output of the fuzzy inference system engine

Table 8. Triangular membership function

\begin{tabular}{cc}
\hline TFN & Linguistic variable \\
\hline$(0,3,5)$ & Low \\
$(3,5,7)$ & Average \\
$(5,7,10)$ & high \\
\hline
\end{tabular}

Figure 4 graphically shows the membership functions defined for input and output variables.

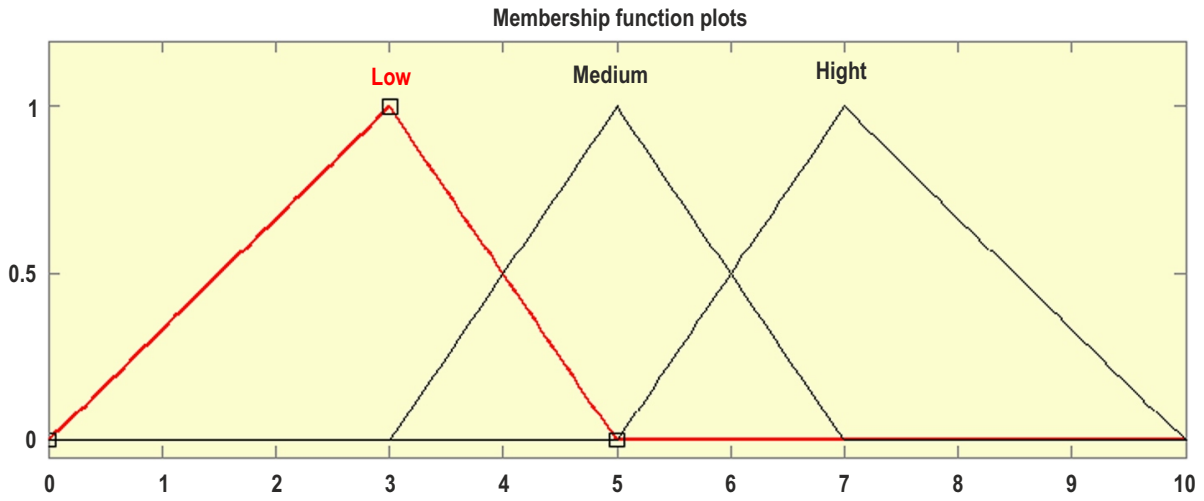

Fig. 4. Membership function of the input and output variables 
Each of the variables of the fuzzy set is defined between 1 and 10. Each of the numbers in the range of functions is between zero and one. As above-mentioned, the functions are individually designed and used for each of the input and output parameters.

\subsection{Fuzzy inference system rules definition}

Then, it is necessary to define fuzzy inference rules to design the fuzzy inference system. Fuzzy inference rules are defined in the form of the IF - THEN rules. These rules show the relation between fuzzy sets and the effectiveness of each of them on the final rating measurement process. In other words, the input data are converted to output data by the use of these rules. To generate the rules, the first questionnaire is designed to define the relationship between input and output components. As well as, the weighting factors for indicators are allocated to obtain the calculated average (final weight of each factor over the total weight of the factors). It should be noted that the upper weight of each variable is applied to calculate the weight of each linguistic variable. In accordance to the adopted factors, each linguistic variable has a different weight as mentioned in Table 9.

Table 9. Final weight and factors normal number

\begin{tabular}{ccccccc}
\hline & $\mathrm{T}$ & $\mathrm{R}$ & $\mathrm{F}$ & $\mathrm{H}$ & $\mathrm{P}$ & Total \\
\hline Factor & Time & Reliability & Flexibility & Human & Profitability & \\
\hline Average number & 2.9381 & 3.0523 & 3.1146 & 2.8063 & 2.9135 & 14.8248 \\
\hline Normal number & 0.198189 & 0.205893 & 0.210090 & 0.189296 & 0.196533 & 1 \\
\hline
\end{tabular}

The weight of each factor is multiplied with the upper bound of each linguistic variable to obtain the rules. The following example is provided to clarify the matter.

The relative weight of $\mathrm{T}$ is considered between zero and one. Regarding to 3 terms of the linguistic variables, the first step should be determining the weight of $\mathrm{T}$ in low, medium and high intervals. This process is repeated for the next 4 factors.

Finally, the results of the different combinations of these 5 factors are concluded. For example, when the $\mathrm{T}$ is low, the $\mathrm{R}$ is medium, the $\mathrm{F}$ is low, the $\mathrm{H}$ is medium and the $\mathrm{P}$ is high, the output value is $M$.

A number of the rules were defined according to the determined levels in order to define the fuzzy rules. Then, by using the current data, some rules were set to calculate the output for the determined input. In other words, a matrix for each of the factors is needed that is resulted from multiplying the linguistic values with the weight of each factor in order to create the fuzzy rules. According to the five final inputs and three linguistic variables, the number of all possible rules is $\left(3^{\star} 3{ }^{\star} 3{ }^{\star} 3 * 3\right)=243$. Some fuzzy rules are shown in Table 10.

This table is applied to calculate an output level for each input combination. In this step, fuzzy logic toolbox in MATLAB software is used to define fuzzy inference rules. The AND operator was used to define rules due to the fact that there is reasonable and appropriate level of co-expression at the same time. Figure 5 shows fuzzy logic toolbox rules that the output is based on the input combinations in Table 10. 
Table 10. Making rules based on factors

\begin{tabular}{|c|c|c|c|c|c|c|c|c|c|c|c|c|}
\hline Role & The $n$ & eight of e & ch factor & Fuzzy nu & Imber & Time & Reliability & Flexibility & Human & Profitability & Total & Output \\
\hline 1 & 0.06606 & 0.06863 & 0.07003 & 0.06310 & 0.06551 & Low & Low & Low & Low & Low & 0.33333 & Low \\
\hline 2 & 0.06606 & 0.06863 & 0.07003 & 0.06310 & 0.13102 & Low & Low & Low & Low & Medium & 0.39884 & Medium \\
\hline 3 & 0.06606 & 0.06863 & 0.07003 & 0.12620 & 0.06551 & Low & Low & Low & Medium & Low & 0.39643 & Medium \\
\hline 4 & 0.06606 & 0.06863 & 0.07003 & 0.06310 & 0.19653 & Low & Low & Low & Low & High & 0.46436 & Medium \\
\hline 5 & 0.06606 & 0.06863 & 0.07003 & 0.18930 & 0.06551 & Low & Low & Low & High & Low & 0.45953 & Medium \\
\hline 6 & 0.06606 & 0.06863 & 0.07003 & 0.12620 & 0.19653 & Low & Low & Low & Medium & High & 0.52745 & Medium \\
\hline 7 & 0.06606 & 0.06863 & 0.07003 & 0.18930 & 0.13102 & Low & Low & Low & High & Medium & 0.52504 & Medium \\
\hline 8 & 0.06606 & 0.06863 & 0.07003 & 0.12620 & 0.13102 & Low & Low & Low & Medium & Medium & 0.46194 & Medium \\
\hline 9 & 0.06606 & 0.06863 & 0.07003 & 0.18930 & 0.19653 & Low & Low & Low & High & High & 0.59055 & Medium \\
\hline 10 & 0.06606 & 0.06863 & 0.14006 & 0.06310 & 0.06551 & Low & Low & Medium & Low & Low & 0.40336 & Medium \\
\hline 11 & 0.06606 & 0.06863 & 0.14006 & 0.06310 & 0.13102 & Low & Low & Medium & Low & Medium & 0.46887 & Medium \\
\hline 12 & 0.06606 & 0.06863 & 0.14006 & 0.12620 & 0.06551 & Low & Low & Medium & Medium & Low & 0.46646 & Medium \\
\hline 13 & 0.06606 & 0.06863 & 0.14006 & 0.06310 & 0.19653 & Low & Low & Medium & Low & High & 0.53439 & Medium \\
\hline 14 & 0.06606 & 0.06863 & 0.14006 & 0.18930 & 0.06551 & Low & Low & Medium & High & Low & 0.52956 & Medium \\
\hline 15 & 0.06606 & 0.06863 & 0.14006 & 0.12620 & 0.19653 & Low & Low & Medium & Medium & High & 0.59748 & Medium \\
\hline 16 & 0.06606 & 0.06863 & 0.14006 & 0.18930 & 0.13102 & Low & Low & Medium & High & Medium & 0.59507 & Medium \\
\hline 17 & 0.06606 & 0.06863 & 0.14006 & 0.12620 & 0.13102 & Low & Low & Medium & Medium & Medium & 0.53197 & Medium \\
\hline 18 & 0.06606 & 0.06863 & 0.14006 & 0.18930 & 0.19653 & Low & Low & Medium & High & High & 0.66058 & Medium \\
\hline 19 & 0.06606 & 0.06863 & 0.21009 & 0.06310 & 0.06551 & Low & Low & High & Low & Low & 0.47339 & Medium \\
\hline 20 & 0.06606 & 0.06863 & 0.21009 & 0.06310 & 0.13102 & Low & Low & High & Low & Medium & 0.53890 & Medium \\
\hline 21 & 0.06606 & 0.06863 & 0.21009 & 0.12620 & 0.06551 & Low & Low & High & Medium & Low & 0.53649 & Medium \\
\hline 22 & 0.06606 & 0.06863 & 0.21009 & 0.06310 & 0.19653 & Low & Low & High & Low & High & 0.60441 & Medium \\
\hline 23 & 0.06606 & 0.06863 & 0.21009 & 0.18930 & 0.06551 & Low & Low & High & High & Low & 0.59959 & Medium \\
\hline 24 & 0.06606 & 0.06863 & 0.21009 & 0.12620 & 0.19653 & Low & Low & High & Medium & High & 0.66751 & High \\
\hline 25 & 0.06606 & 0.06863 & 0.21009 & 0.18930 & 0.13102 & Low & Low & High & High & Medium & 0.66510 & Medium \\
\hline$\vdots$ & $\vdots$ & $\vdots$ & $\vdots$ & $\vdots$ & $\vdots$ & $\vdots$ & $\vdots$ & $\vdots$ & $\vdots$ & $\vdots$ & $\vdots$ & $\vdots$ \\
\hline 217 & 0.19819 & 0.20589 & 0.07003 & 0.06310 & 0.06551 & High & High & Low & Low & Low & 0.60272 & Medium \\
\hline 218 & 0.19819 & 0.20589 & 0.07003 & 0.06310 & 0.13102 & High & High & Low & Low & Medium & 0.66823 & High \\
\hline 219 & 0.19819 & 0.20589 & 0.07003 & 0.12620 & 0.06551 & High & High & Low & Medium & Low & 0.66582 & Medium \\
\hline 220 & 0.19819 & 0.20589 & 0.07003 & 0.06310 & 0.19653 & High & High & Low & Low & High & 0.73374 & High \\
\hline 221 & 0.19819 & 0.20589 & 0.07003 & 0.18930 & 0.06551 & High & High & Low & High & Low & 0.72892 & High \\
\hline 222 & 0.19819 & 0.20589 & 0.07003 & 0.12620 & 0.19653 & High & High & Low & Medium & High & 0.79684 & High \\
\hline 223 & 0.19819 & 0.20589 & 0.07003 & 0.18930 & 0.13102 & High & High & Low & High & Medium & 0.79443 & High \\
\hline 224 & 0.19819 & 0.20589 & 0.07003 & 0.12620 & 0.13102 & High & High & Low & Medium & Medium & 0.73133 & High \\
\hline 225 & 0.19819 & 0.20589 & 0.07003 & 0.18930 & 0.19653 & High & High & Low & High & High & 0.85994 & High \\
\hline 226 & 0.19819 & 0.20589 & 0.14006 & 0.06310 & 0.06551 & High & High & Medium & Low & Low & 0.67275 & High \\
\hline 227 & 0.19819 & 0.20589 & 0.14006 & 0.06310 & 0.13102 & High & High & Medium & Low & Medium & 0.73826 & High \\
\hline 228 & 0.19819 & 0.20589 & 0.14006 & 0.12620 & 0.06551 & High & High & Medium & Medium & Low & 0.73585 & High \\
\hline 229 & 0.19819 & 0.20589 & 0.14006 & 0.06310 & 0.19653 & High & High & Medium & Low & High & 0.80377 & High \\
\hline 230 & 0.19819 & 0.20589 & 0.14006 & 0.18930 & 0.06551 & High & High & Medium & High & Low & 0.79895 & High \\
\hline 231 & 0.19819 & 0.20589 & 0.14006 & 0.12620 & 0.19653 & High & High & Medium & Medium & High & 0.86687 & High \\
\hline 232 & 0.19819 & 0.20589 & 0.14006 & 0.18930 & 0.13102 & High & High & Medium & High & Medium & 0.86446 & High \\
\hline 233 & 0.19819 & 0.20589 & 0.14006 & 0.12620 & 0.13102 & High & High & Medium & Medium & Medium & 0.80136 & High \\
\hline 234 & 0.19819 & 0.20589 & 0.14006 & 0.18930 & 0.19653 & High & High & Medium & High & High & 0.92997 & High \\
\hline 235 & 0.19819 & 0.20589 & 0.21009 & 0.06310 & 0.06551 & High & High & High & Low & Low & 0.74278 & High \\
\hline 236 & 0.19819 & 0.20589 & 0.21009 & 0.06310 & 0.13102 & High & High & High & Low & Medium & 0.80829 & High \\
\hline 237 & 0.19819 & 0.20589 & 0.21009 & 0.12620 & 0.06551 & High & High & High & Medium & Low & 0.80588 & High \\
\hline 238 & 0.19819 & 0.20589 & 0.21009 & 0.06310 & 0.19653 & High & High & High & Low & High & 0.87380 & High \\
\hline 239 & 0.19819 & 0.20589 & 0.21009 & 0.18930 & 0.06551 & High & High & High & High & Low & 0.86898 & High \\
\hline 240 & 0.19819 & 0.20589 & 0.21009 & 0.12620 & 0.19653 & High & High & High & Medium & High & 0.93690 & High \\
\hline 241 & 0.19819 & 0.20589 & 0.21009 & 0.18930 & 0.13102 & High & High & High & High & Medium & 0.93449 & High \\
\hline 242 & 0.19819 & 0.20589 & 0.21009 & 0.12620 & 0.13102 & High & High & High & Medium & Medium & 0.87139 & High \\
\hline 243 & 0.19819 & 0.20589 & 0.21009 & 0.18930 & 0.19653 & High & High & High & High & High & 1 & High \\
\hline
\end{tabular}

For example, this condition is assigned to the first fuzzy rule: "IF time factor in the implementation is low, reliability is low, flexibility is low, human factor is low and profitability is low, THEN the success evaluation of the business process is low". 


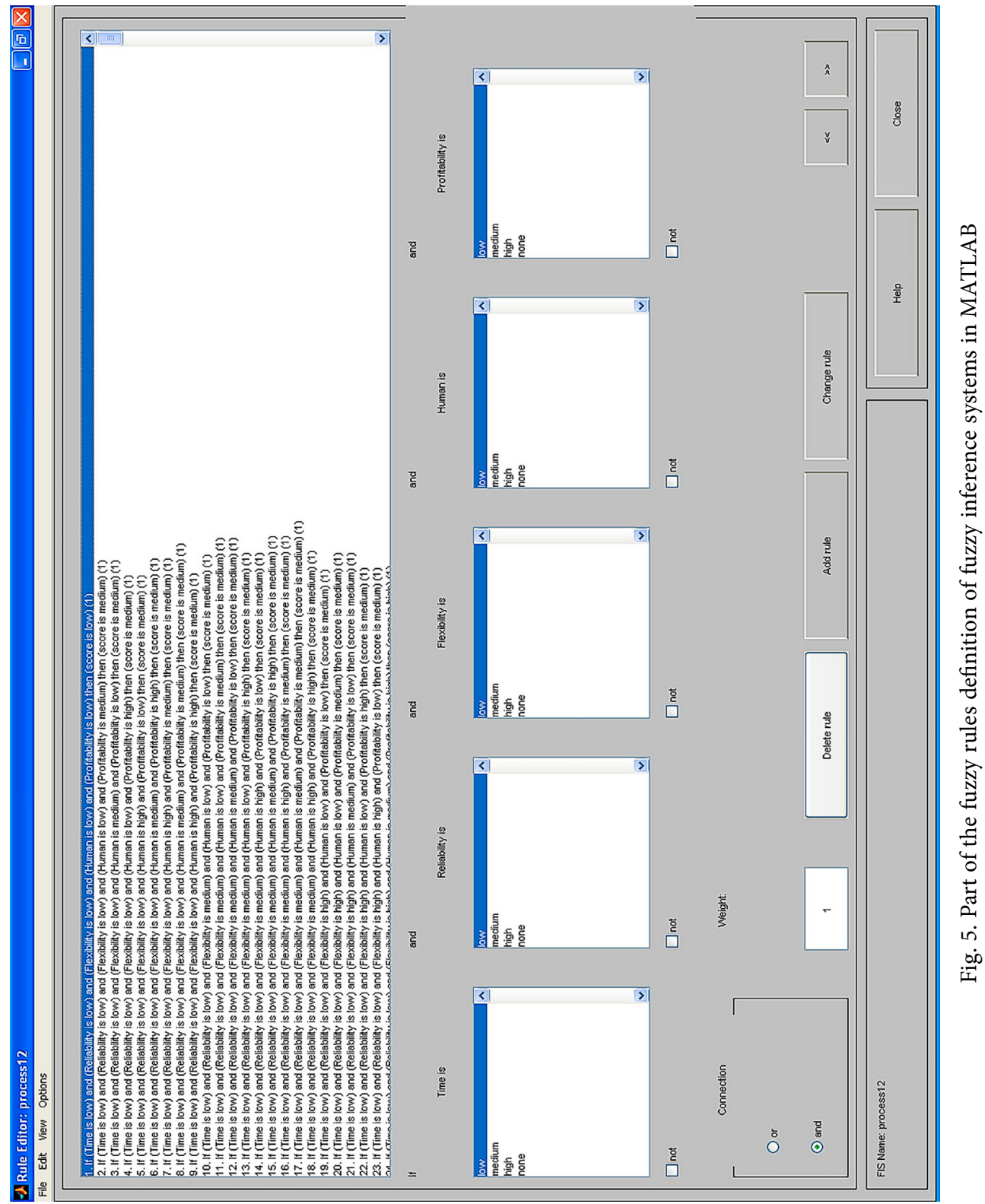




\section{Designing the business process for payment system (Case Study)}

The second questionnaire (with the same question from the first questionnaire) which is designed to scoring the business process in the area of payment systems was distributed among experts. We asked the expert team to assign a score between one and ten based on each indicator for each of the business processes. Then, the weight of the five main factors was calculated.

It should be noted that the Interbank Information Transfer Network (IITN) system is an electronic banking clearance and automated payments system used in Iran (Named SHETAB). The SHETAB system was introduced in 2002 with the intention of creating a uniform backbone for the Iranian banking system to handle ATM, POS and other cardbased transactions.

The primary business process is shown in Figure 6. It is improved and shown in Figure 7 and the reengineering is shown in Figure 9. Designing the processes is done by the use of Visual Paradigm software that supports Business Process Model and Notation (BPMN). The main goal is to reduce delays and prevent organizations from paying additional costs. Also, the goal is to divide the primary activity into simpler activities to combine the two consecutive operations and to eliminate the couple loops and cycles (Zarandi 2011).

The improved business process, in which the role of information technology and information sending via internet is emphasized, is depicted in Figure 7. The business process reengineering, as shown in Figure 9, illustrates how to eliminate the customers' presence in order to reduce the duration of the business process from 2 days to 3 hours. It should be noted that when there is a discrepancy in IITN, the problem is resolved within 2 working days.

Each of the other indicators is in interaction with business process and experts' opinions are reflected through questionnaires in the fuzzy system.

\subsection{Analysis of the first business process}

The first business process in Figure 7 is actually the reformed version of the previous business process in Figure 6.

Based on Figure 7, the results of the business process evaluation are shown in Table 11. The input function domain, a number between 0 and 10, is the system input.

Table 11. Weights of the reformed business process factors

\begin{tabular}{cc}
\hline Factor & weight \\
\hline Time & 4.56 \\
\hline Reliability & 5.15 \\
\hline Flexibility & 3.48 \\
\hline Human & 5.16 \\
\hline Profitability & 6.17 \\
\hline
\end{tabular}


After calculating the factors weight and inserting them in MATLAB software, the score of the reformed business process can be obtained. The weights of the five factors in fuzzy logic toolbox of MATLAB software can be seen in Figure 8. Each of the lines in the figure shows a rule and each column is related to an input variable which is shown on the left side. The value of the output variable is shown on the right side. The red vertical lines can be used to set the input.
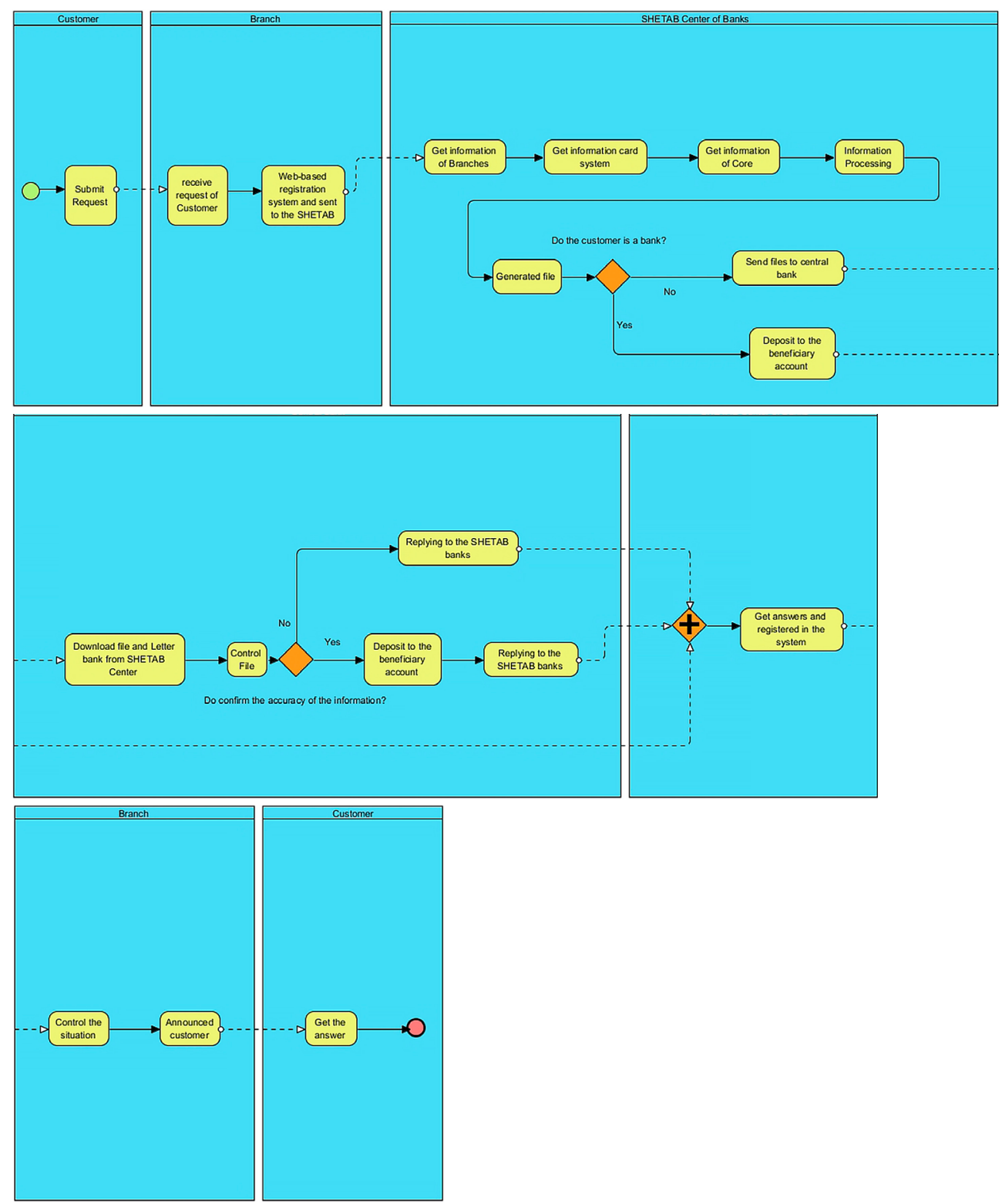

Fig. 6. The primary IITN (SHETAB) business process 


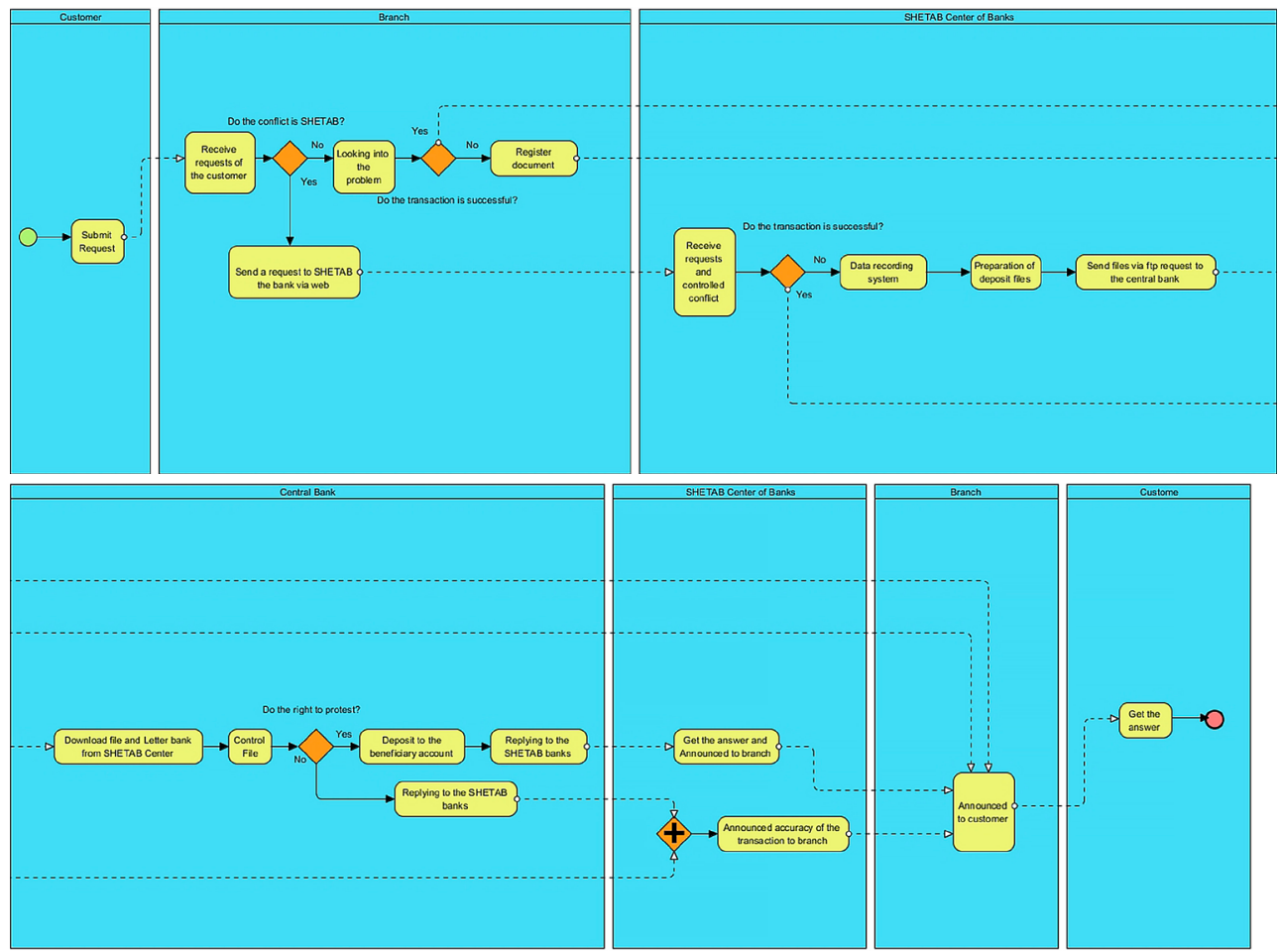

Fig. 7. The improved IITN (SHETAB) business process

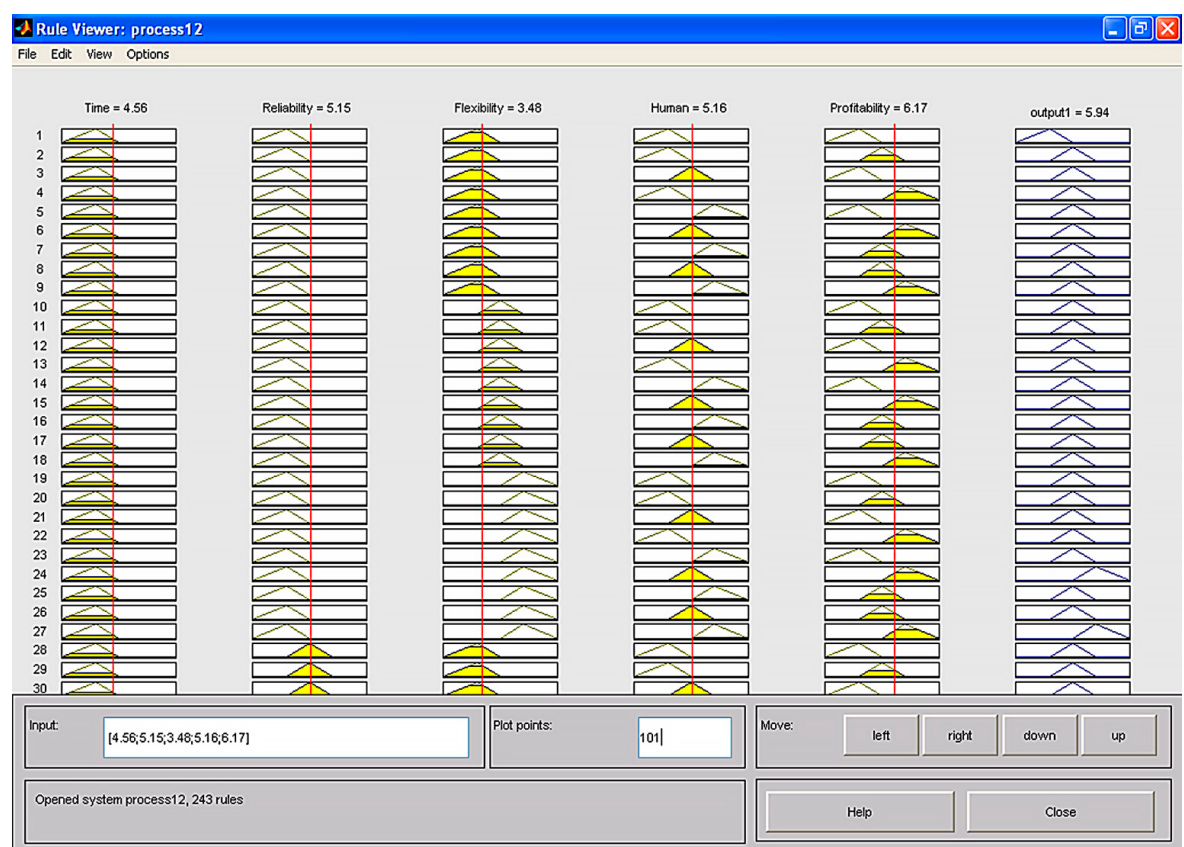

Fig. 8. Final score of IITN in the reformed business process 
Finally, the software reflects the final score of the output variable. The software examines the fuzzy inference rules after receiving the input. Then, it determines the output level by finding the related rule. The output should be defuzzified to show the system score in the form of a crisp number. The centroid method is used for the defuzzification process. The centroid point is the area that its right and left surface under the arc are the same. It is automatically determined by the software.

As shown in Figure 8, the value of 5.94 is obtained as the first business process scoring by entering the weight of the business factors as inputs of fuzzy inference system.

\subsection{Analysis of the second business process}

The designed business reengineering process can be seen in Figure 9.

The results of the second questionnaire of business reengineering process (Fig. 9) can be seen in Table 12 .

It's time to calculate the IITN business reengineering process score by entering the results in MATLAB software. The results can be seen in Figure 10.

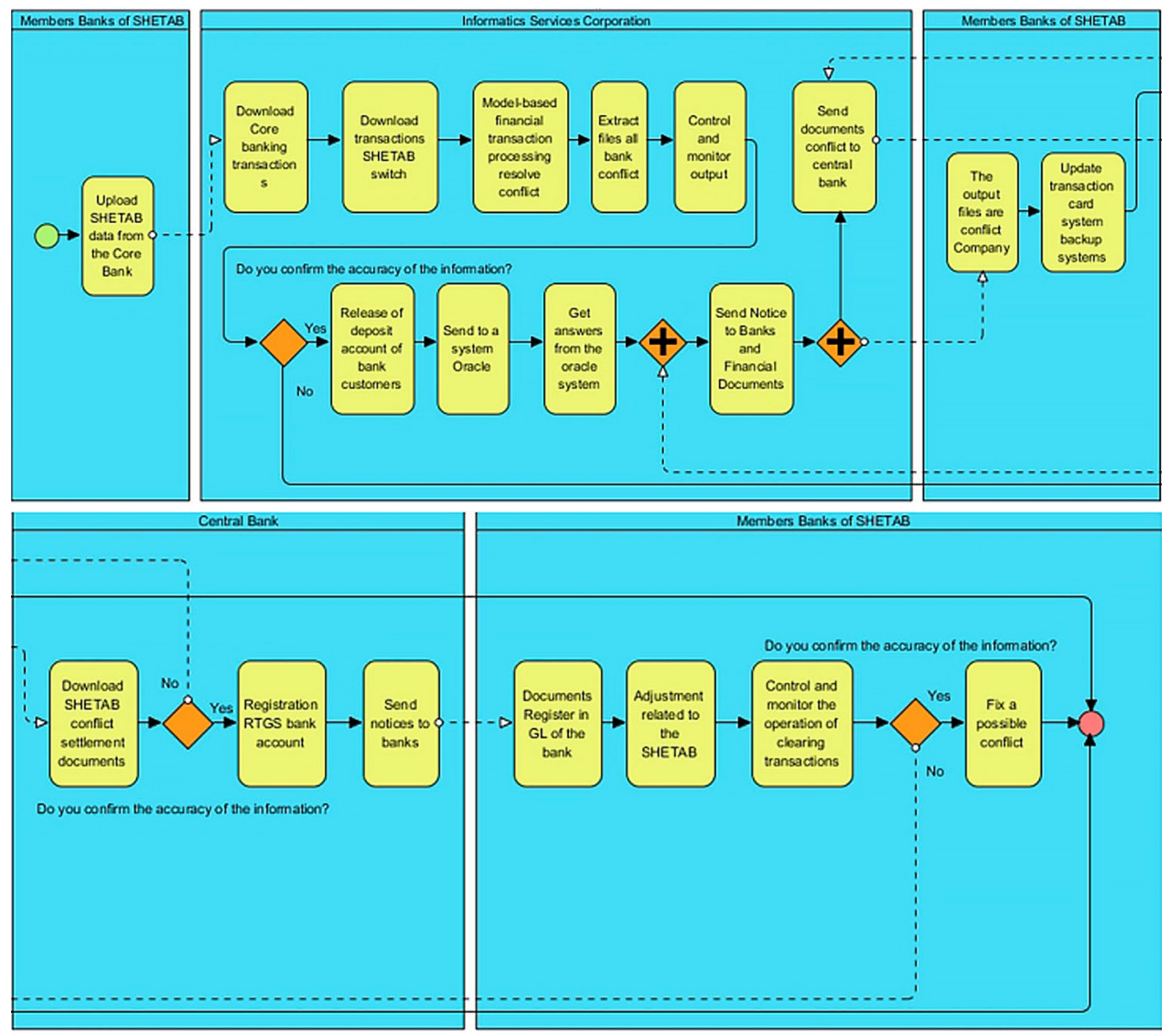

Fig. 9. IITN (SHETAB) Reengineering 
Table 12. Weights of the reengineering business process factors

\begin{tabular}{cc}
\hline Factor & weight \\
\hline Time & 6.46 \\
\hline Reliability & 8.16 \\
\hline Flexibility & 7.18 \\
\hline Human & 7.29 \\
\hline Profitability & 6.68 \\
\hline
\end{tabular}

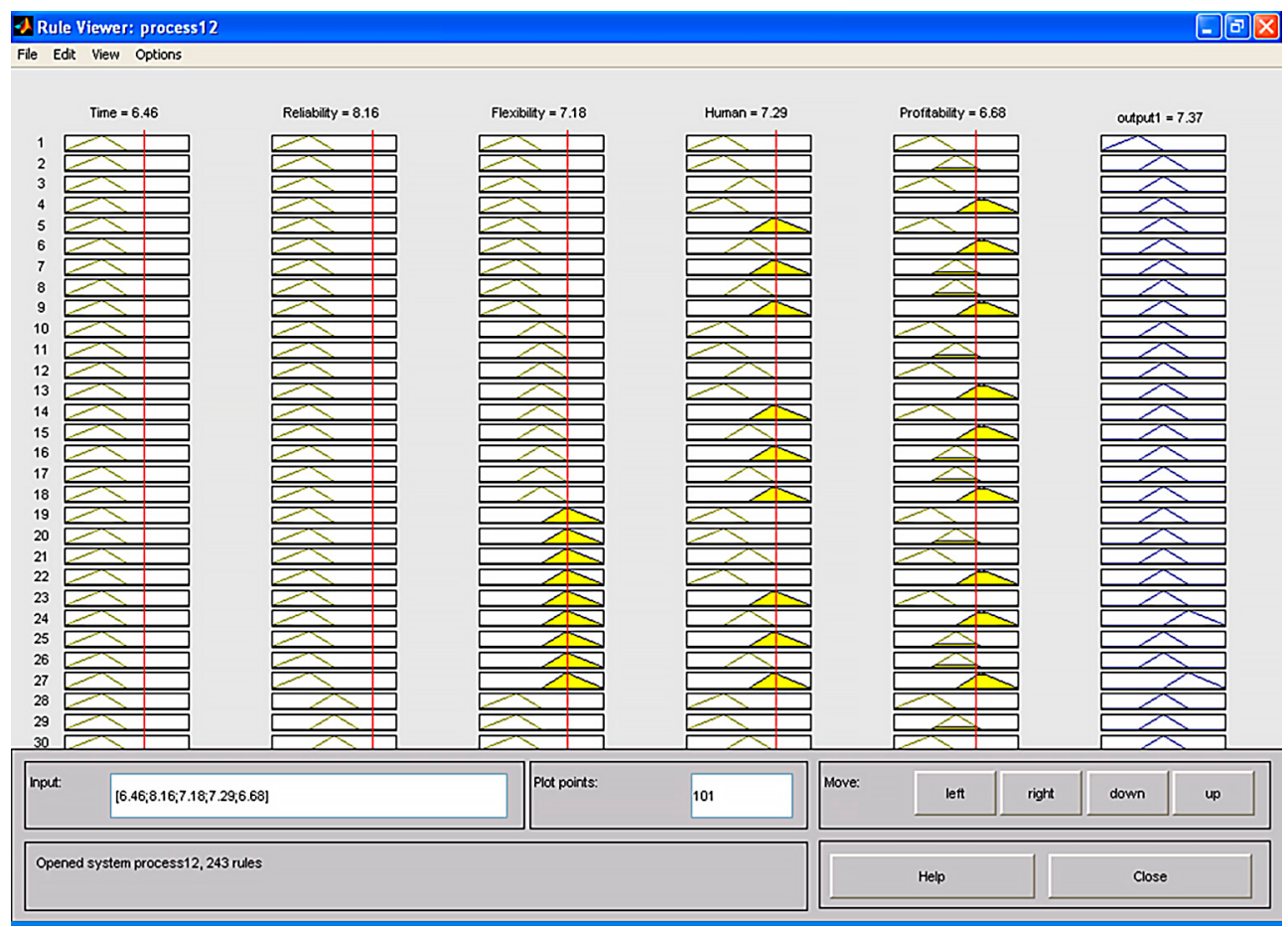

Fig. 10. Final reengineering score

As seen in Figure 10, the value of 7.37 is obtained as the second business process scoring by entering the weight of the IITN business reengineering process factors as the inputs of fuzzy inference system.

Table 13. Final score of business process

\begin{tabular}{cc}
\hline Process & Final score \\
\hline Modified & 5.94 \\
Reengineering & 7.37 \\
\hline
\end{tabular}

It can be seen in Table 13 that business reengineering process score is higher. 


\section{Conclusions}

The present study has the following results and advantages in comparison to the previous studies:

- Providing a useful system to enable organizations to reach success by entering their own input indicators.

- The collected indicators that are effective in business process selection are more comprehensive than the indicators in previous studies.

- Previous studies were forced to eliminate some of the indicators, but in this study because of its approach - there was no need to eliminate any indicator.

- The fuzzy approach and fuzzy inference system that are used to score the business processes are more useful approaches for obtaining the better results.

- Fuzzy logic approach increases the reliability of the business process evaluation and prevents the organizations from paying additional costs.

- Because of using experts' opinion and determined indicators, this approach can be used in all generative and service-provided organizations.

Therefore, organizations should evaluate their own designed processes in banking payment systems by using the five factors in order to be successful.

According to the results of the present study, the following recommendations seem necessary for future research:

- The weight of each indicator in non-linear form in addition to the selected and codified indicators helps to the clarification of the business process score.

- Using a larger Statistical population and examining more banks and organizations helps to the system be comprehensively evaluated.

- The results of the present study should be evaluated by a wider community of experts and, if possible, at the international level.

- We need intelligent systems and a combination of fuzzy logics and neural networks to optimize the system. If it is done, the system will provide us with the best business processes.

- The organizations can localize the main factors in their own business processes by using exploratory factor analysis and fuzzy logic methods.

\section{References}

Afrazeh, A. 2011. Knowledge management. Tehran: Amirkabir University of Technology.

Akhavan, P.; Barak, S.; Maghsoudlou, H.; Antucheviciene, J. 2015. FQSPM-SWOT for strategic alliance planning and partner selection; case study in a holding car manufacturer company, Technological and Economic Development of Economy 21(2): 165-185.

http://dx.doi.org/10.3846/20294913.2014.965240

Anderson, J. C.; Gerbing, D. W. 1988. Structural equation modeling in practice: a review and recommended two-step approach, Psychological Bulletin 103: 411-423.

http://dx.doi.org/10.1037/0033-2909.103.3.411 
Azizi, F.; Bagherzadeh, G.; Mombeini, H. 2014. Relationship marketing strategy and customers' satisfaction in the third millennium organizations (case study: banking Industry), International Journal of Scientific Management and Development 2(12): 728-732.

Baležentis, A.; Baležentis, T.; Brauers, W. K. M. 2012. MULTIMOORA-FG: a multi-objective decision making method for linguistic reasoning with an application to personnel selection. Informatica 23(2): 173-190.

Bausys, R.; Zavadskas, E. K. 2015. Multicriteria decision making approach by VIKOR under interval neutrosophic set environment, Economic Computation and Economic Cybernetics Studies and Research 49(4): 33-48.

Bausys, R.; Zavadskas, E. K.; Kaklauskas, A. 2015. Application of neutrosophic set to multicriteria decision making by COPRAS, Economic Computation and Economic Cybernetics Studies and Research 49(2): 91-105.

Binesh, M. 2005. Gary Hamel ideas, Tadbir Monthly Magazine 157: 55-59.

Boran, S.; Goztepe K.; Yavuz, E. A study on election of personnel based on performance measurement by using analytic network process (ANP). International Journal of Computer Science and Network Security 8(4): 333-338.

Bourne, M. 2000. Designing, implementing and updating performance measurement systems, International Journal of Operations \& Production Management 20(7): 754-771. http://dx.doi.org/10.1108/01443570010330739

Brignall, S.; Ballantine, J. 1996. Performance measurement in service business revisited, International Journal of Service Industry Management 7(1): 6-31. http://dx.doi.org/10.1108/09564239610109393

Brignall, T. J.; Fitzgerald, L.; Johnston, R.; Silvestro, R. 1991. Product costing in service organisations, Management Accounting Research 2(4): 227-248. http://dx.doi.org/10.1016/S1044-5005(91)70036-X

Buckley, J. J. 1985. Fuzzy hierarchical analysis, Fuzzy Sets and Systems 17(3): 233-247. http://dx.doi.org/10.1016/0165-0114(85)90090-9

Champy, J. 1995. Reengineering management: the mandate for new leadership. New York: Harper Business.

Davis, L.; Blenkinsop, S. 1991. The road to continuous improvement, Insight 4(3): 23-26. http://dx.doi.org/10.1057/ori.1991.21

Delgado, A.; Weber, B.; Ruiz, F.; Guzmán, I. G. R.; Piattini, M. 2014. An integrated approach based on execution measures for the continuous improvement of business processes realized by services, Information and Software Technology 56(2): 134-162. http://dx.doi.org/10.1016/j.infsof.2013.08.003

Efendigil, O. S. K. C. 2009. A decision support system for demand forecasting with artificial neural networks and neuro-fuzzy models: a comparative analysis, Expert Systems with Applications 36(3): 6697-6707. http://dx.doi.org/10.1016/j.eswa.2008.08.058

Epstein, M. J.; Manzoni, J. F. 1997. The balanced scorecard and tableau de bord: translating strategy into action, Management Accounting (August): 28-36.

Ferreira, F. A. F.; Santos, S. P.; Rodrigues, P. M. M.; Spahr, R. W. 2014. How to create indices for bank branch financial performance measurement using MCDA techniques: an illustrative example, Journal of Business Economics and Management 15(4): 708-728.

http://dx.doi.org/10.3846/16111699.2012.701230

Field, A. 2000. Discovering statistics using SPSS for Windows. New Delhi: Sage Publication.

Foster, G. 1986. Financial statement analysis. 2nd ed. New Jersey: Prentice Hall.

Fry, T. D.; Cox, J. F. 1989. Manufacturing performance; local versus global measures, Production and Inventory Management Journal 2: 52-56. 
Ghalayini, A. M.; Noble, J. S.; Crowe, T. J. 1997. An integrated dynamic performance measurement system for improving manufacturing competitiveness, International Journal of Production Economics 48(3): 207-225. http://dx.doi.org/10.1016/S0925-5273(96)00093-X

Globerson, S.; Ellis, S. 1996. Analysis of learning profiles in project environments, in Project Mangement Institute Conference, October 1996, Boston.

Hamel, G. 2009. The architects of the digital age, Tadbir Monthly Magazine 155: 78-83.

Kaplan, R. S.; Norton, D. P. 1992. The balanced scorecard measures that drive performance, Harvard Business Review 70(1): 71-79.

Karami, G. R.; Talaeei, L. 2013. Predictability of stock returns using financial ratios in the companieslisted in Tehran Stock Exchange, International Research Journal of Applied and Basic Sciences 5(3): 360-372.

Kaya, I.; Kahraman, C. 2014. A comparison of fuzzy multicriteria decision making methods for intelligent building assessment, Journal of Civil Engineering and Management 20(1): 59-69. http://dx.doi.org/10.3846/13923730.2013.801906

Keegan, D. P.; Eiler, R. G.; Jones, C. R. 1989. Are your performance measures obsolete?, Management Accounting 70(12): 45-50.

Kennerley, M.; Neely, A. 2002. A framework of the factors affecting the evolution of performance measurement systems, International Journal of Operations \& Production Management 22(11): 12221245. http://dx.doi.org/10.1108/01443570210450293

Khandekar, A. V.; Antuchevičienė, J.; Shankar, Ch. 2015. Small hydro-power plant project selection using fuzzy axiomatic design principles, Technological and Economic Development of Economy 21(5): 756-772. http://dx.doi.org/10.3846/20294913.2015.1056282

Lynch, R. L.; Cross, K. F. 1991. Measure up! Yardsticks for continuous improvement. Oxford: Basil Blackwell.

Mansar, L. S.; Reijers, H. A. 2007. Best practices in business process redesign: use and impact, Business Process Management Journal 13(2): 193-213. http://dx.doi.org/10.1108/14637150710740455

Maskell, B. 1989. Just in time implementing: the new strategy. Carol Stream-Illinois, United States: Hitchcock Publishing.

Maull, R. 2003. Factors characterising the maturity of BPR programmes, International Journal of Operations \& Production Management 23(6): 596-624. http://dx.doi.org/10.1108/01443570310476645

Meyer, A.; Zimmermann, H. 2011. Applications of fuzzy technology in business intelligence, International Journal of Computers Communications \& Control 6(3): 428-441. http://dx.doi.org/10.15837/ijccc.2011.3.2128

Mombeini, H.; Bagherzadeh, G.; Ghorbani, R. 2014. The role of information technology in enhancing partnerships of manager - employee, International Journal of Management and Humanity Sciences 3(11): 3579-3585

Morselli, A. 2015. The decision-making process between convention and cognition, Economic \& Sociology 8(1): 205-221. http://dx.doi.org/10.14254/2071-789X.2015/8-1/16

Motamedifar, M. 2008. Implementation of information security standard (ISO 27001) in organizations. Tehran: Scientific-Educational Center of Applied Industrial Research of Iran.

Neely, A. 1998. Three models of measurement: theory and practice, International Journal of Business Performance Management 1(1): 47-64. http://dx.doi.org/10.1504/IJBPM.1998.004544

Neely, A. 1999. The performance measurement revolution:why now and what next?, International Journal of Operations \& Production Management 19: 205-228. http://dx.doi.org/10.1108/01443579910247437

Neely, A. D.; Adams, C. 2002. The performance prism: the scorecard for measuring and managing business success. Financial Times Prentice Hall. 
Neely, A. D.; Bourne, M.; Kennerley, M. 2000. Performance measurement system design: developing and testing a process-based approach, International Journal of Operations \& production Management 20(10): 1119-1145. http://dx.doi.org/10.1108/01443570010343708

Neely, A.; Gregory, M. 1995. Performance measurement system design: a literature review and research agenda, International Journal of Operations \& Production Mangement 15(4): 80-116. http://dx.doi.org/10.1108/01443579510083622

Nouri, A. F.; Khalili Esbouei, S.; Antucheviciene, J. 2015. A hybrid MCDM approach based on fuzzy ANP and fuzzy TOPSIS for technology selection, Informatica 26(3): 369-388. http://dx.doi.org/10.15388/Informatica.2015.53

Obolensky, N. 1997. Re-engineering and managing change in organizations. First Edition. Tehran: Arvin published.

Podviezko, A.; Podvezko, V. 2014. Absolute and relative evaluation of socio-economic objects based on multiple criteria decision making methods, Inzinerine ekonomika-Engineering economics 25(5): 522-529. http://dx.doi.org/10.5755/j01.ee.25.5.6624

Reijers, H. A.; Mansar, L. S. 2005. Best practices in business process redesign: an overview and qualitative evaluation of successful redesign heuristics, International Journal of Management Science 33(4): 283-306. http://dx.doi.org/10.1016/j.omega.2004.04.012

Rikhtegar, N.; Mansouri, N.; Oroumieh, A. A.; Yazdani-Chamzini, A.; Zavadskas, E. K.; Kildiene, S. 2014. Environmental impact assessment based on group decision-making methods in mining projects, Economic Research-Ekonomska Istrazivanja 27(1): 378-392. http://dx.doi.org/10.1080/1331677X.2014.966971

Saaty, T. L. 1980. The analytic hierarchy process. New York: McGraw Hill.

Smith, A. 1776. An inquiry into the nature and causes of the wealth of nations. 1st ed. London: W. Strahan. http://dx.doi.org/10.1093/oseo/instance.00043218

Spremic, M.; Zmirak, Z. 2008. IT and business process performance management: case study of ITIL implementation in finance service industry, in 30th International Conference on Information Technology Interfaces, 23-26 June 2008, Cavtat, Croatia. http://dx.doi.org/10.1109/iti.2008.4588415

Stanujkic, D.; Zavadskas, E. K.; Tamosaitiene, J. 2015. An approach to measuring website quality in the rural tourism industry based on Atanassov Intuitionistic Fuzzy Sets, E \& M Ekonomie a Management 18(4): 184-199. http://dx.doi.org/10.15240/tul/001/2015-4-013

Susniene, D.; Purvinis, O. 2015. Empirical insights on understanding stakeholder influence, Journal of Business Economics and Management 16(4): 845-860. http://dx.doi.org/10.3846/16111699.2013.785974

Temponi, C.; Harris, C. 1998. Overview of fuzzy systems in reengineering in Fuzzy Information Processing Society - NAFIPS, 1998 Conference of the North American, 20-21 August 1998, 110-114. http://dx.doi.org/10.1109/NAFIPS.1998.715547

Teymori, E.; Aliakbari, M. H. 2009. Measuring business performance. Tehran: Science and Technology University.

Treki, A.; Urban, B. 2015. Drivers of effective renewable energy policies, Engineering Economics 26(3): 306-314.

Trkman, P. 2010. The critical success factors of business process management, International Journal of Information Management 30(2): 125-134. http://dx.doi.org/10.1016/j.ijinfomgt.2009.07.003

Wainwright, D.; Green, G.; Mitchell, E.; Yarrow, D. 2005. Towards a framework for benchmarking ICT practice, competence and performance in small firms, The International Journal for Library and Information Services 6(1): 39-52. http://dx.doi.org/10.1108/14678040510588580

Wisner, J. D.; Fawcett, S. E. 1991. Linking firm strategy to operating decisions through performance measurement, Production and Inventory Management Journal (Third quarter): 5-11. 
Wu, D. 2009. Measuring performance in Small and Medium Enterprises in the information and communication technology industries. Doctoral thesis, RMIT University.

Yazdani-Chamzini, A.; Shariati, Sh.; Yakhchali, S. H.; Zavadskas, E. K. 2014. Proposing a new methodology for prioritising the investment strategies in the private sector of Iran, Economic ResearchEkonomska Istrazivanja 27(1): 320-345. http://dx.doi.org/10.1080/1331677X.2014.947150

Zarandi, F. M. H. 2011. Modeling of large organizations: principles and applications. Tehran: Amirkabir University of Technology.

Zarandi, F. M. H. 2010. Fuzzy set theory principles and functions. Tehran: Amirkabir University of Technology.

Ghasem BAGHERZADEH is a graduate of M.S. from IE \& MS in Amirkabir University of Technology, Tehran, Iran. He has published some papers and articles regarding banking industry. He is working in $\mathrm{R} \& \mathrm{D}$ division in bank Keshavarzi of Iran (BKI). He has done some projects related to Payment systems. His main interests are BPR \& BPM, Information Technology and Fuzzy Systems.

Kaveh M. CYRUS is the tenure Assistance Professor at Department of Industrial Engineering \& Management Systems (IE \& MS) Department in Amirkabir University of Technology, Tehran, Iran, since 1990. He has obtained his PhD from Amirkabir University of Technology and his ED and MS from University of Southern California. He has been the director of Pars Engineering Management Research Center since 2006. He has published three books related to Strategic Management, Leadership and Organization and has published and presented many papers and articles regarding Enterprise Integration Engineering and the above-mentioned subjects in International Journals, Conferences and Seminars. He has developed and published a competitive model for local companies and organizations strategic planning facing country entering WTO (World Trading Organization). He is the member of Iranian Society of Industrial Engineering (co-founder and one of first Board of Directors' members) and Iran Management Association (ex-Chairman of the Board of Directors).

Abdolreza YAZDANI-CHAMZINI is PhD student in the Dept of Management, Research Assistant of Fateh Reaserch Group, Tehran-Iran. Author of more than 60 research papers. In 2011 he graduated from the Science and Engineering Faculty at Tarbiat Modares University, Tehran-Iran. His research interests include decision making, forecasting, modeling, and optimization.

Algita MIEČINSKIENĖ is PhD in Economics (Vilnius Gediminas Technical University, Lithuania), an Associate Professor at the Department of Finance Engineering, a head of Finance Engineering Department at Vilnius Gediminas Technical University (Lithuania). She is an author of more than 50 research papers. Her research interests are business decisions in uncertain environment, multinational corporate economics and finance, effective pricing, foreign direct investment (greenfield investment, mergers and acquisitions) and finance engineering. 